\title{
Kajian Elektrolit Polimer berasaskan Getah Asli Terubah Suai (MG49) dalam Sel Suria Terpeka Pewarna
}

(An Investigation of Modified Natural Rubber-Based (MG49) Polymer Electrolyte in Dye-Sensitized Solar Cells)

Shuhib Mamat, Mohamad Faizzi, Mohd Sukor Su'Ait*, Norasikin Ahmad Ludin, KamaruZZAman Sopian,

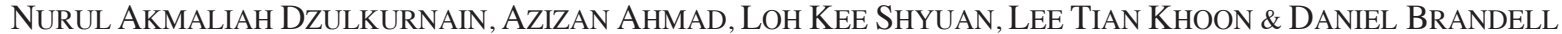

\section{ABSTRAK}

Kajian terhadap elektrolit polimer berasaskan 49\% poli(metil metakrilat) cangkukan getah asli (MG49) dengan natrium iodida (NaI) dalam aplikasi sel suria terpeka pewarna (DSSC) telah dijalankan. Kesan kepekatan garam ke atas sifat elektrokimia, morfologi, kimia dan kehabluran MG49-NaI telah dianalisis menggunakan spektroskopi impedan elektrokimia (EIS), mikroskopi imbasan elektron (SEM), spektroskopi inframerah transformasi Fourier (FTIR) dan pembelauan sinar-X (XRD). Morfologi keratan rentas menunjukkan struktur membran berliang mikro dan homogen. Nilai kekonduksian ion tertinggi pada suhu bilik bagi membran elektrolit polimer MG49-NaI pada penambahan $30 \%$ bt. garam NaI adalah $8.86 \times 10^{-5} \mathrm{~S} \mathrm{~cm}$. Analisis inframerah menunjukkan interaksi antara atom oksigen dengan ion natrium berlaku pada kumpulan berfungsi eter $(\mathrm{C}-\mathrm{O}-\mathrm{C})$ dan karbonil $(\mathrm{C}=\mathrm{O})$. Sifat kehabluran MG49-NaI polimer elektrolit didapati berkurang dengan peningkatan kepekatan garam. Analisis kronoamperometri memberikan nilai nombor pindahan ion $\left(t_{i o n}\right)$ sebanyak 0.92 membuktikan elektrolit polimer MG49-NaI (30 \% bt.) adalah pengkonduksi jenis ion. Ujian prestasi DSSC keadaan pepejal bagi FTO/TiO $-\mathrm{N719/MG49-NaI} \mathrm{(30 \%} \mathrm{bt.)/I} \mathrm{/} \mathrm{Pt} \mathrm{sampel} \mathrm{telah} \mathrm{memberikan}$ keputusan kecekapan setinggi $0.26 \%$ dengan prestasi fotovoltaik, $J_{s c}, V_{o c}$ danff masing-masing adalah $1.30 \mathrm{~mA} \mathrm{~cm}^{-2}, 0.56$ $V$ dan 34.91. Membran dalam keadaan pepejal-kuasi atau separa pepejal memberikan nilai kecekapan $3.48 \%$ dengan nilai $V_{o c}=0.75 \mathrm{~V}_{\mathrm{sc}}=12.71 \mathrm{~mA} \mathrm{~cm}^{-2}$ dan $\mathrm{FF}=37.70$.

Kata kunci: Elektrolit polimer; natrium iodida (NaI); sel suria terpeka pewarna (DSSC); 49\% poli(metil metakrilat) cangkukan getah asli (MG49)

\section{ABSTRACT}

A dye-sensitized solar cell (DSSC) was fabricated utilizing 49\% poly(methyl methacrylate)-grafted natural rubber (MG49) with sodium iodide (NaI) as ion conducting membrane. The effect of NaI concentrations on electrochemical, morphological, chemical interaction and the crystallinity properties of MG49 has been analyzed by electrochemical impedance spectroscopy (EIS), scanning electron microscopy (SEM), Fourier transform infrared spectroscopy (FTIR) and X-ray diffraction (XRD), respectively. The highest ionic conductivity of $8.86 \times 10^{-5} \mathrm{~S} \mathrm{~cm}^{-1}$ at room temperature for MG49-NaI (30 wt. \%) polymer electrolyte membrane is achieved. The cross-sectional morphology showed a homogenous microporous structure of the membrane. Infrared analysis indicated that the interactions occurred between oxygen atoms from ether $(C-O-C)$ and carbonyl $(C=O)$ group of the polymer with sodium ions. XRD analysis showed the property of semi-crystalline phase reduced with the increases of salt concentration. The chronoamperometry analysis of MG49$\mathrm{NaI}$ (30 wt. \%) give an ionic transference number value of 0.92, proving that the polymer electrolyte membrane is ionic conductor and predominates by the number of ions presence. A fabricated solid-state dye-sensitized solar cell (DSSC) of

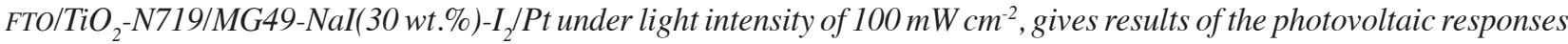
with $J_{s c}, V_{o c}, f f$ and efficiency of $1.30 \mathrm{~mA} \mathrm{~cm} \mathrm{~cm}^{-2}, 0.56 \mathrm{~V}, 34.91$ and $0.26 \%$, respectively. In quasi-solid DSSC, an effieciency of $3.48 \%$ with $V_{o c}=0.75 \mathrm{~V}, J_{s c}=12.71 \mathrm{~mA} \mathrm{~cm}^{-2}$ and $F F=37.70$ was achieved.

Keywords: Dye-sensitized solar cell (DSSC); polymer electrolyte; sodium iodide (NaI); 49\% poly(methyl methacrylate) grafted natural rubber (MG49)

\section{PENGENALAN}

Sejak kebelakangan ini, kehausan sumber bahan api seperti arang batu, gas asli dan petroleum serta krisis terhadap permintaan tenaga elektrik yang semakin meningkat secara drastik amat membimbangkan. Suruhanjaya Tenaga Malaysia telah menganggarkan jumlah simpanan minyak mentah di Semenanjung Malaysia telah berkurang sebanyak 50\% pada tahun 2013 berbanding pada tahun 1993 (Suruhanjaya Tenaga 2016). Statistik sumber tenaga pada tahun 2016 juga menunjukkan peningkatan permintaan kepada sumber tenaga yang sebahagian besarnya didominasi oleh sumber tenaga tidak keterbaharu seperti sumber minyak mentah (36.1\%), gas asli (43.4\%), arang batu (16.6\%) dan selebihnya terdiri daripada sumber 
keterbaharu (3.9\%). Statistik ini juga menunjukkan $87.7 \%$ daripada jumlah tenaga elektrik yang dijana pada tahun 2014, adalah disumbang dari stesen janakuasa terma yang sebahagian besarnya menggunakan sumber seperti gas asli (43.8\%) dan arang batu (43.2\%) sebagai bahan api utama untuk menggerakkan turbin. Manakala, sistem janakuasa solar hanya menyumbang $0.2 \%$ daripada jumlah penjanaan tenaga pada tahun tersebut. Walau bagaimanapun, peningkatan sumber daripada tenaga suria dapat diperhatikan secara drastik sejak ia diperkenalkan pada tahun 2012 daripada 11 ktoe kepada 75 ktoe pada tahun 2015 (Malaysia Energy Information Hub 2016) dan dijangkakan berlaku lonjakkan drastik selepas kerajaan Malaysia melalui Suruhanjaya Tenaga membuka tender ladang solar berskala besar dengan kapasiti 360 MWac di semenanjung Malaysia dan 100 MWac di Sabah/Labuan menjelang tahun 2020.

Bertuahnya, Malaysia yang terletak di garisan khatulistiwa menerima hampir $400-600 \mathrm{MJ} / \mathrm{m}^{2}$ tenaga yang disumbangkan oleh cahaya matahari. Oleh yang demikian, Malaysia berpotensi besar menjadi peneraju dalam industri solar. Pada masa kini, Malaysia merupakan negara ketiga terbesar bagi pengeluar dan pembuatan modul sel fotovoltaik di dunia. Hal ini seiring dengan program pelan lantai solar PV Malaysia 2030 yang menyasarkan penjanaan tenaga sehingga 2,080 MW daripada sumber keterbaharuan tenaga pada tahun 2030 .

Justeru, sejak berdekad yang lalu, para penyelidik menfokuskan kajian saintifik terhadap pembangunan dan pengoptimuman tenaga sel suria. Kini, tumpuan telah banyak difokuskan kepada sel suria generasi ketiga yang berasaskan kepada bahan organik atau bahan hibrik organik-tidak organik (Green 2001). Sejak penemuan sel suria terpeka pewarna (DSSC) oleh Grätzel and O'Regan pada tahun 1991, DSSC terbukti sebagai salah satu sel suria fotovoltaik (PV) generasi ketiga yang berpotensi tinggi dalam teknologi pembuatan sel fotovoltaik (O’Regan et al. 1991). Antara ciri-ciri DSSC yang paling menarik adalah kos pengeluaran yang lebih murah. Hal ini sedemikian kerana bahan yang digunakan adalah mudah diperoleh, tidak bertoksik dan kos pembuatan yang rendah mengurangkan penggunaan tenaga seterusnya menjimatkan proses pengilangan. Walau bagaimanapun, kecekapan keseluruhan berkurangan pada kadar yang lebih pantas berbanding dengan sel suria berasaskan silikon konvensional akan tetapi kadar toleransi kecekapan penukaran kuasa yang tinggi pada keadaan cahaya yang pelbagai terutamanya di bawah cahaya buatan dan keadaan berawan yang banyak terdapat di kawasan berkelembapan tinggi seperti di Malaysia menarik perhatian penyelidik untuk terus berusaha memperbaiki peranti ini (Bella 2015; Su'ait et al. 2015). Untuk sel solar monokristal Si, kecekapan tertinggi telah mencapai $23.3 \%$ pada tahun 2016 oleh Kaneka Corp., Jepun manakala sel solar perovskit tertinggi direkodkan pada $22.1 \%$ oleh Institut Penyelidikan Teknologi Kimia Korea (KRICT) dan Institut Sains and Teknologi Kebangsaan Ulsan (UNIST), Korea Selatan pada tahun 2016 (Green et al. 2017).
Sehingga kini, kecekapan penukaran kuasa tertinggi DSSC masih bergantung kepada elektrolit jenis cecair dengan menggunakan spesies redoks berasaskan kobalt (II/III) bersama-sama dengan tert-butil piridin (TBP) dan $\mathrm{LiClO}_{4}$ dalam asetonitril sebagai pelarut dan zinkpemeka porfirin (SM315) untuk meningkatkan prestasinya sehingga 13\% (Matthew et al. 2014). Baru-baru ini, Kakiage et al. (2015) dari ADEKA Corp., Jepun telah memperoleh lebih daripada 14\% kecekapan dengan sel suria terpeka dengan pemeka bersama antara pewarna ADEKA-1 dengan kumpulan penambat alkoksil dan pewarna organik LEG4 dengan kumpulan penambat karboksil. Seterusnya kecekapan $15 \%$ telah direkodkan pada DSSC keadaan pepejal menggunakan bahan perovskit sebagai bahan penuai cahaya antara struktur $\mathrm{TiO}_{2}$ dan bahan pengangkut lohong, Spiro-OMeTAD oleh saintis École Polytechnique Fédérale de Lausanne (EPFL) pada tahun 2013 (Burschka et al. 2013). Dalam kajian ini DSSC berasaskan pasangan redoks iodida-triiodida yang mencapai kecekapan penukaran kuasa sehingga $11.18 \%$ digunakan sebagai piawai kawalan (Nazeeruddin et al. 2005).

Peranti DSSC terdiri daripada 4 komponen utama iaitu fotoanod, pemeka pewarna, elektrolit dan elektrod lawan. Fotoanod terdiri daripada bahan semikonduktor oksida mesoporous seperti titanium dioksida $\left(\mathrm{TiO}_{2}\right)$, yang dienapkan di atas permukaan substrat kaca bersalut oksida timah terdop florin, F: $\mathrm{SnO}_{2}$ (FTO) dan kemudiannya dipeka dengan pewarna sebagai penyerap cahaya pada struktur mesoporous $\mathrm{TiO}_{2}$. Struktur mesoporous $\mathrm{TiO}_{2}$ yang mempunyai jurang jalur yang luas bertindak sebagai penjerap pewarna yang mengumpul elektron terjana cahaya hasil daripada foton yang diserap. Seterusnya, elektron yang terkumpul disuntik ke dalam jalur pengalir $\mathrm{TiO}_{2}$ seterusnya menjana arus bagi pengoperasian pada litar terluar. Pemeka pewarna kembali kepada keadaan asal apabila menerima elektron yang didermakan oleh elekrolit yang mengandungi sistem redoks iaitu pasangan iodida/ triiodida $\left(\mathrm{I}^{-} / \mathrm{I}_{3}^{-}\right)$dan berlakunya pengoksidaan $\mathrm{I}^{-}$kepada $\mathrm{I}_{3}^{-}$. Selepas itu, I- dijana semula pada elektrod lawan melalui tindak balas penurunan $\mathrm{I}_{3}^{-}$. Elektrod lawan mengandungi bahan pemangkin, seperti platinum $(\mathrm{Pt})$ yang dienapkan atas permukaan FTO bagi mempercepatkan tindak balas penurunan bagi $\mathrm{I}_{3}^{-}$dengan elektron daripada litar terluar (Grätzel 2003). Garam iodida telah digunakan secara meluas sebagai perantara redoks dalam DSSC disebabkan oleh keserasian jurang tenaganya dengan pewarna N719 yang dipekakan ke atas fotoelektrod $\mathrm{TiO}_{2}$ (Wu et al. 2015). Berikutnya, Ibrahim et al. (2018, 2015) telah menjalankan kajian kesan jenis garam iodida terhadap poliuretena (PU) untuk aplikasi DSSC. Daripada kajian beliau, didapati nilai kekonduksian ion bagi PU-LiI (30\% bt.) adalah lebih tinggi berbanding dengan PU-NaI (30\% bt.) iaitu $1.78 \times 10^{-6} \mathrm{~S}$ $\mathrm{cm}^{-1}$ dan $4.28 \times 10^{-7} \mathrm{~S} \mathrm{~cm}^{-1}$. Walau bagaimanapun, nilai kecekapan penukaran kuasa DSSC pula tidak memberikan perbezaan yang ketara dengan sistem DSSC berasaskan polimer elektrolit PU-NaI dan PU-LiI masing-masing adalah $0.80 \%$ dan $0.83 \%$. 
Walau bagaimanapun, penggunaan elektrolit cecair yang mengandungi pelarut organik yang mudah terpeluap berhadapan dengan masalah kehilangan medium pelarut tersebut melalui kebocoran dan penyejatan di dalam DSSC konvensional. Keadaan ini akan mengakibatkan jangka hayat DSSC terhad pada satu jangka masa pendek walaupun dijangkakan mampu bertahan selama 20 tahun. Hal ini mendorong para saintis untuk mencari penyelesaian alternatif ke arah penggunaan elektrolit dalam keadaan pepejal.

Lantaran itu, DSSC menggunakan elektrolit polimer gel (GPE) telah berjaya dibangunkan dan mempunyai kestabilan yang lama dan kecekapan penukaran kuasa yang tinggi (Mohan et al. 2017). Penggunaan elektrolit polimer mempunyai kelebihan daripada segi lekatan dengan elektrod serta kemudahan dalam proses fabrikasi sel suria. Elektrolit polimer terdiri daripada garam dan polimer dengan polimer bertindak sebagai medium pelarut kepada bahan larut, iaitu garam. Antaranya, penggunaan poli(1-vinilpirolidon-ko-vinil asetat) (PVP-co-VAc) dengan kecekapan penukaran kuasa sebanyak $4.67 \%$ ( $\mathrm{Ng}$ et al. 2015). Buraidah et al. (2017) melaporkan kecekapan penukaran kuasa yang tinggi oleh DSSC iaitu sebanyak 9.61\% dengan mengunakan ftaliol kitosan sebagai GPE.

Perkembangan elektrolit daripada getah terubah suai juga menunjukkan perkembangan yang positif sejak akhir-akhir ini. Antaranya, penggunaan getah asli terubah suai sebagai polimer perumah seperti $50 \%$ getah asli terepoksida (ENR50), 30\% poli(metil metakrilat) (PMMA) cangkukan getah asli (MG30) dan 49\% PMMA cangkukan getah asli (MG49) yang mampu mencapai kekonduksian ion yang tinggi. Pencangkukan monomer metil metakrilat (MMA) pada lateks getah semula jadi (struktur kimia ditunjukkan dalam Rajah 1) pertama kali dilaporkan pada tahun 1967 oleh Waterman et al. (1967) tetapi ia hanya mula mendapat perhatian pada pertengahan abad ke-20; kerana ciri-ciri kekutuban dan suhu peralihan kaca, $T_{\mathrm{g}}$ yang rendah (untuk mobiliti rantaian yang lebih baik). Glasse et al. (2002) menyedari hal ini dan membuktikan fungsi getah asli terubah suai sebagai medium untuk mengangkut ion. Kajian lanjut menunjukkan monomer MMA mampu bertindak sebagai bahagian keras bagi tulang belakang rantai polimer dan memiliki kumpulan berpolar seperti karbonil $(\mathrm{C}=\mathrm{O})$ serta eter $(\mathrm{C}-\mathrm{O}-\mathrm{C})$. Kedua-dua kumpulan ini mempunyai atom oksigen yang berfungsi sebagai atom elektron penderma yang akan berinteraksi dengan ion bercas positif ataupun kation seterusnya menyumbang kepada mobiliti ion (Kumutha et al. 2005). Manakala, struktur isoprena pada getah asli menyumbang kepada sifat fizikal dan mekanik elektrolit seperti kebolehlenturan dan keanjalan. Di samping itu, MG49 memiliki keistimewaannya yang tersendiri dengan suhu peralihan kaca $\left(T_{\mathrm{g}}\right)$ yang rendah yang dapat membantu dalam meningkatkan pengerakan rantai polimer. Ali et al. (2013) telah menghasilkan elektrolit polimer pepejal MG30-LiTf yang mencatatkan kekonduksian ion yang tinggi iaitu $8.95 \times 10^{-3} \mathrm{~S} \mathrm{~cm}^{-1}$. Antara kajian awal yang telah menggunakan elektrolit berasaskan getah asli untuk diaplikasikan dalam DSSC telah dilakukan oleh Silakul dan Magaraphan (2013). Mereka telah menggunakan elektrolit gel polimer berasaskan poliakrilamida cangkukan getah asli (PAM- $g$-NR) dan adunan PAM- $g$-NR dengan polipirol yang direndam dalam cecair elektrolit $0.3 \mathrm{M} \mathrm{LiI}, 0.015 \mathrm{M}$ $\mathrm{I}_{2}$, dan $0.1 \mathrm{M}$ TBP. Walau bagaimanapun, mereka tidak melaporkan kecekapan DSSC sehinggalah penerbitan pada tahun berikutnya. Mereka telah memfabrikasi DSSC keadaan pepejal-kuasi menggunakan poli(3-(trimetoksilil) propil metakrilat) cangkukan getah asli (PMPS- $g$-NR) yang direndam dalam cecair elektrolit yang sama. Hasilnya, kecekapan fotovoltaik tertinggi didapati pada $0.01 \%$ dengan nilai kekonduksian ion optimum, $7.75 \times 10^{-4} \mathrm{~S}$ $\mathrm{cm}^{-1}$ (Silakul \& Magaraphan 2014). Pada tahun 2017, Silakul dan Magaraphan telah melaporkan peningkatan kecekapan fotovoltik yang lebih tinggi, daripada $1.6 \%$ kepada $3.5 \%$ menggunakan elektrolit gel polimer poli(asid akrilik-ko-(trimetoksilil) propil metakrilat) cangkukan getah asli tercangkuk silika asapan (PAA-NRco-MPS-SiO ) yang direndam dalam elektrolit cecair yang ditambah baik dengan 0.1M 1-butil-3-metilimidazolium iodida. Kekonduksian ion bertambah daripada $7.67 \times$ $10^{-4} \mathrm{~S} \mathrm{~cm}^{-1}$ ke $9.31 \times 10^{-4} \mathrm{~S} \mathrm{~cm}^{-1}$. Sementara itu, Nazir et al. (2017) melaporkan penyediaan elektrolit polimer gel berasaskan $30 \%$ poli(metil metakrilat) (PMMA) cangkukan getah asli terepoksida (EMG30) dengan garam $\mathrm{LiCF}_{3} \mathrm{SO}_{3}$ mencatatkan kekonduksian ion sebanyak 4.83 $\times 10^{-3} \mathrm{~S} \mathrm{~cm}^{-1}$. Meskipun kajian tersebut bertujuan untuk diaplikasi dalam DSSC, penulis tidak memfabrikasi peranti selanjutnya bagi memerhati prestasi sel menggunakan elektrolit yang disediakan. Sebagai kritikan lanjut, peranti DSSC keadaan pepejal kuasi yang telah difabrikasi itu menggunakan elektrolit gel polimer ini dijangkakan tidak mampu memberikan sebarang gerak balas fotoarus tanpa kehadiran pasangan redoks. Manakala beberapa kajian lain berkaitan elektrolit berasaskan getah terubah suai, MG49 turut dijalankan untuk aplikasi bateri litium sekunder seperti MG49-PVdF-HFP-LiBF 4 (Ataollahi et al. 2012), MG49-PMMA-LiClO 4 (Su'ait et al. 2009), MG49$\mathrm{SnO}_{2}-\mathrm{LiBF}_{4} / \mathrm{LiClO}_{4}$ (Ahmad et al. 2012) dan MG49$\mathrm{ZrO}_{2}-\mathrm{TiO}_{2}-\mathrm{LiCF}_{3} \mathrm{SO}_{3}$ (TianKhoon et al. 2015). Keputusan kajian menunjukkan kesemua elektrolit memberikan perkembangan yang positif dalam kekonduksian ion serta memiliki ciri mekanik sepadan seperti fleksibel dan elastik.

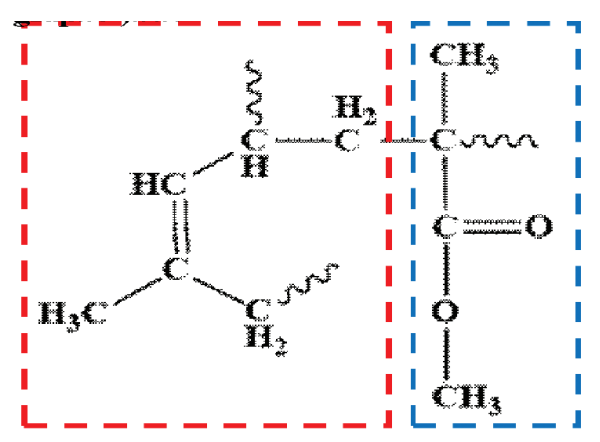

RAJAH 1. Struktur kimia MG49 
Dalam kajian ini, penyelidikan awal bagi penggunaan polimer perumah berasaskan getah asli terubah suai, MG49 dengan garam natrium iodida (NaI) sebagai elektrolit polimer di dalam sel suria terpeka pewarna (DSSC) dilaporkan. Sepanjang pengetahuan kami. kajian terhadap penggunaan MG49 dalam DSSC adalah pertama dan tidak ada penerbitan yang dijumpai. Garam NaI digunakan kerana ia adalah lebih murah dibanding dengan garam LiI. Melalui laman jaringan Sigma-Aldrich, harga bagi 100 g garam NaI dan LiI adalah USD366 dan USD430. Selain itu, sumber garam natrium adalah banyak dan mudah diperoleh. Seperti dinyatakan sebelum ini, walaupun garam LiI memberikan kekonduksian ion yang lebih baik berbanding dengan garam $\mathrm{NaI}$, prestasi kedua-dua polimer elektrolit ini dalam DSSC adalah tidak ketara, Oleh itu, keputusan kajian ini mampu menjadi pemangkin dan permulaan yang baru dalam penerokaan elektrolit berasaskan getah asli dalam aplikasi sel suria.

\section{BAHAN DAN KAEDAH}

\section{BAHAN}

$49 \%$ poli(metil metakrilat) cangkukan getah asli (MG49) yang juga dikenali secara komersial sebagai 'MEGAPOLY' diperoleh daripada Green HPSP (M) Sdn. Bhd. (Petaling Jaya, Malaysia). Natrium iodida $(\mathrm{NaI})$ dan iodin $\left(\mathrm{I}_{2}\right)$ dibekalkan oleh Sigma-Aldrich (St. Louis, Mo, USA). Semua komponen DSSC, pes platinum dengan nama komersial 'Platisol T', pewarna N719 dan kaca florin terdop timah oksida (FTO) setebal $3 \mathrm{~mm}$ dengan $15 \Omega /$ $\mathrm{cm}^{2}$ sebagai oksida pengkonduksi lutsinar dibekalkan oleh solaronix (Aubonne, Switzerland). Bahan pelarut organik tetrahidrofuran (THF) diperoleh daripada Systerm ChemAR (Poland). Kesemua bahan digunakan tanpa melalui sebarang proses penulenan yang selanjutnya.

\section{KAEDAH PENYEDIAAN SAMPEL}

Teknik pengacauan larutan digunakan dalam penyediaan sampel elektrolit polimer pepejal. MG49 seberat 1.5 $\mathrm{g}$ dipotong kepada saiz kecil dan dilarutkan di dalam $30 \mathrm{~mL}$ THF selama 24 jam. Seterusnya, larutan MG49 dikacau selama 24 jam sehingga larutan menjadi likat dan jernih. Pada masa yang sama, $10 \%$ bt. garam NaI dilarutkan dalam kelalang berbeza yang mengandungi $10 \mathrm{~mL}$ larutan THF dan dikacau selama 12 jam sehingga larut. Selepas itu, larutan garam tersebut dicampurkan ke dalam larutan MG49 sedikit demi sedikit dan dikacau selama 24 jam. Kemudian, larutan elektrolit polimer yang terhasil dituang ke dalam piring petri Teflon dan dibiarkan meruap pada suhu bilik sehingga membentuk filem. Bagi menyingkirkan pelarut yang masih terperangkap di dalam membran, pengeringan seterusnya dijalankan di dalam ketuhar vakum pada suhu $50^{\circ} \mathrm{C}$ selama 24 jam. Sampel berikutnya disimpan di dalam desikator untuk perincian selanjutnya. Kaedah penyediaan yang sama diulang dengan menggunakan peratus berat garam $\mathrm{NaI}$ yang berbeza pada kadar $15 \%$ bt. sehingga $30 \%$ bt.

\section{KAEDAH PENCIRIAN SAMPEL}

Pengukuran kerintangan pukal dijalankan menggunakan teknik spektroskopi impedan elektrokimia berjenama Princeton: model VersaSTAT4 pada julat frekuensi $1 \mathrm{MHz}$ hingga $0.1 \mathrm{~Hz}$ dengan $50 \mathrm{mV}$ amplitud. Pengukuran ini dijalankan pada suhu persekitaran dan pada julat suhu daripada $303 \mathrm{~K}$ hingga $403 \mathrm{~K}$. Membran elektrolit polimer pepejal berbentuk cakera dengan luas bersamaan 1.767 $\mathrm{cm}^{2}$ diapit oleh dua keluli tahan karat sebagai elektrod penyekat. Kekonduksian ion dikira dengan menggunakan persamaan berikut:

$$
\sigma=1 /\left(\mathrm{A} \times \mathrm{R}_{b}\right)
$$

dengan $l$ adalah ketebalan filem; $A$ ialah luas kawasan bersentuhan antara membran dengan elektrod $(A=1.767$ $\left.\mathrm{cm}^{2}\right)$; dan $R_{\mathrm{b}}$ ialah kerintangan pemindahan cas di dalam elektrolit. Nombor pindahan ion bagi kekonduksian tertinggi elektrolit polimer pepejal (MG49-NaI) diperoleh melalui kaedah kronoamperometri menggunakan VersaSTAT 4 dengan keupayaan $0.01 \mathrm{~V}$ pada suhu bilik. Nombor pindahan ion $\left(t_{\text {ion }}\right)$ dikira menggunakan persamaan berikut:

$$
t_{\text {ion }}=\left(I_{\mathrm{T}}-I_{\mathrm{S}}\right) / I_{\mathrm{T}}
$$

dengan $I_{\mathrm{T}}$ dan $I_{\mathrm{S}}$ adalah jumlah dan keadaan mantap arus masing-masing (Bruce et al. 1988). Morfologi permukaan sampel diperhatikan dengan menggunakan mikroskop imbasan elektron (SEM) model ZEISS, SUPRA $55 \mathrm{VP}$ dengan $3000 \times$ pembesaran pada $15 \mathrm{kV}$ pancaran elektron. Sebelum analisis dijalankan, sampel dipatahkan terlebih dahulu di dalam menggunakan cecair nitrogen dan disadur dengan lapisan emas berkilauan. Kumpulan berfungsi dan interaksi kimia dalam elektrolit MG49-NaI diteliti dengan menggunakan mod pantulan keseluruhan yang dilemahkan (ATR) dalam spektroskopi inframerah transformasi Fourier (FTIR). Spektroskopi FTIR direkod menggunakan spektrometer Spektrum 400 berjenama Perkin Elmer dalam julat frekuensi 4000 hingga 650 $\mathrm{cm}^{-1}$ dengan resolusi imbasan $4 \mathrm{~cm}^{-1}$. Kehabluran sampel elektrolit ditentukan oleh pembelauan sinar-X (XRD) model D-5000 Siemen (Cu-K $\alpha ; \alpha=1.5418 \AA$ A ). Data XRD direkodkan pada julat sudut belauan $2 \theta$ dari $5^{\circ}$ hingga $80^{\circ}$ pada kadar imbasan $0.04^{\circ} \mathrm{s}^{-1}$.

\section{KAEDAH FABRIKASI DAN PENCIRIAN SEL SURIA TERPEKA PEWARNA}

Fabrikasi sel suria dilakukan mengikut piawai daripada Syarikat Solaronix. Pes titania oksida $\left(\mathrm{TiO}_{2}\right)$ diratakan di atas permukaan kaca FTO menggunakan kaedah bilahdoktor dan kemudian dipanaskan pada suhu $500^{\circ} \mathrm{C}$ selama 30 min untuk mengubah fasa anatase kepada fasa rutile. 
Kaca FTO elektrod lawan bersadur platinum disediakan dengan teknik berus lukisan dan dibakar pada suhu $450^{\circ} \mathrm{C}$ selama 10 min bagi mengaktifkan lapisan lutsinar kuasi platinum. Seterusnya, kaca FTO bersalut titania oksida tersebut dipekakan dalam $3 \mathrm{mM}$ larutan pewarna N719 pada suhu bilik selama 12 jam. Membran sebagai elektrolit polimer pepejal MG49-NaI/I 2 pada nisbah molar 1:0.1 difabrikasi antara $\mathrm{TiO}_{2}$ fotoanod dan platinum elektrod lawan. Arus-voltan (I-V) DSSC (FTO/TiO $-\mathrm{N} 719 / \mathrm{MG} 49$ $\mathrm{NaI} / \mathrm{I}_{2} / \mathrm{Pt}$ ) diukur dalam keadaan gelap dan pencahayaan diperoleh dengan menggunakan punca berarus tinggi Keithley model 237 berserta punca cahaya Xenon di bawah jisim udara (AM) 1.5 dan pencahayaan (keamatan cahaya $100 \mathrm{~mW} \mathrm{~cm}^{-2}$ ) dikawal oleh meter lux. Data pengukuran arus-voltan $(I-V)$ digunakan untuk mengira prestasi fotovoltaik (seperti faktor pengisi,ff dan kecekapan penukaran tenaga cahaya kepada tenaga elektrik, $\eta \%$ ) menggunakan persamaan seperti berikut:

$$
f f=\frac{V_{\text {max }} \times J_{\max }}{V_{o c} \times J_{s c}}
$$

dengan $V_{\text {oc }}$ adalah voltan litar terbuka (V); $J_{\text {sc }}$ ialah ketumpatan arus litar pintas $\left(\mathrm{mA} \mathrm{cm}^{-2}\right)$; dan $P_{\text {in }}$ ialah keamatan cahaya tuju $\left(\mathrm{mW} \mathrm{cm}^{-2}\right)$. Sementara itu, $V_{\max }$ dan $J_{\max }$ masing-masing adalah voltan (V) dan ketumpatan arus $\left(\mathrm{mA} \mathrm{cm}^{-2}\right)$ dalam lengkung $J-V$ pada titik maksimum pengeluaran kuasa.

\section{KEPUTUSAN DAN PERBINCANGAN}

\section{ANALISIS IMPEDAN}

Perubahan nilai rintangan MG49-NaI dengan kandungan garam (10-30 \% bt.) ditunjukkan dalam Rajah 2. Plot impedan kompleks menunjukkan dua bahagian berbeza dengan jelas. Kawasan semi bulatan dalam julat frekuensi tinggi mewakili proses kerintangan yang berlaku dalam elektrolit. Nilai rintangan didapati daripada padanan plot yang terbaik pada bulatan separa termampat oleh unsur kapasitor tidak-unggul menggunakan litar-setara unsur fasa malar (CPE) yang disambung secara selari dengan perintang $(R)$, manakala kawasan garis lulus dalam julat frekuensi rendah pula dipadankan oleh CPE yang disumbang oleh kesan elektrod penyekat.

Secara keseluruhannya, kekonduksian ion meningkat dengan penambahan kandungan garam $\mathrm{NaI}$ dan mencapai kekonduksian ion tertinggi pada $8.86 \times 10^{-5} \mathrm{~S} \mathrm{~cm}^{-1}$ dengan penambahan $30 \%$ bt. garam NaI. Kekonduksian ion ini dapat dikaitkan dengan persamaan $\left(\sigma=c e\left(u_{+}+u_{-}\right)=c \Lambda\right)$, $\sigma$ ialah kekonduksian ion; $\Lambda$ ialah kekonduksian molar; $c$ ialah kepekatan garam; $e$ ialah cas elektron; $u_{+}$dan $u_{-}$mewakili mobiliti ion. Daripada persamaan tersebut, peningkatan kekonduksian ion adalah disebabkan oleh peningkatan kepekatan garam yang membawa kepada peningkatan jumlah pembawa cas di dalam sistem elektrolit dengan kepekatan garam adalah paramater pemboleh ubah. Dalam kajian terdahulu berkaitan elektrolit polimer yang menggunakan MG49 sebagai polimer perumah, kekonduksian ion tertinggi dicatatkan adalah $2.3 \times 10^{-7}$ $\mathrm{S} \mathrm{cm}^{-1}$ dan $4.0 \times 10^{-8} \mathrm{~S} \mathrm{~cm}^{-1}$ masing-masing dengan menggunakan garam $\mathrm{LiBF}_{4}(20 \%$ bt.) (Su'ait et al. 2012) dan $\mathrm{LiClO}_{4}$ (15\% bt.) (Su'ait et al. 2009). Hal ini menunjukkan garam $\mathrm{NaI}$ adalah lebih seseuai digunakan dalam sistem polimer elektrolit MG49.

Walau bagaimanapun, penambahan kepekatan garam yang lebih tinggi selepas tahap maksimum akan menyebabkan sampel menjadi tidak stabil dan bentuk tidak sekata. Selain itu, kepekatan garam yang tinggi adalah cenderung untuk berlakunya penyatuan garam semula dengan interaksi antara $\mathrm{Na}^{+}$dan $\mathrm{I}^{-}$akan menjadi cukup kuat untuk membentuk pasangan ion yang seimbang dengan ion yang bebas, iaitu $\mathrm{Na}^{+}+\mathrm{I}^{-} \rightleftharpoons[\mathrm{NaI}]^{0}$. Pasangan ion $\mathrm{NaI}$ ini tidak akan memberikan cas dan sejurusnya akan mengakibatkan kemerosatan kekonduksian ion.

Untuk menentukan kekonduksian sistem MG49-NaI adalah disumbangkan oleh ion-ion dan bukan elektron,

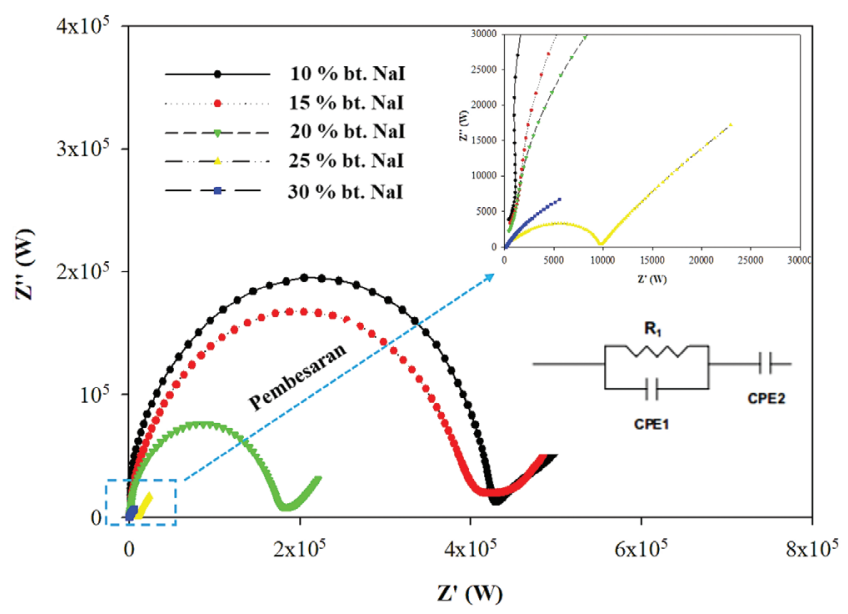

RAJAH 2. Plot Nyquist MG49-NaI pada berat peratus garam NaI berbeza pada suhu $303 \mathrm{~K}$ 
analisis kronoamperometri telah dilakukan dengan elektrolit polimer MG49-NaI (30 \% bt.) telah diuji di dalam sel simetri yang menggunakan keluli tahan karat sebagai elektrod penyekat. Daripada graf arus (I) melawan masa ( $t$ ) (Jadual 1), didapati nilai nombor pindahan ion adalah 0.92 . Hal ini menandakan sistem pengangkutan cas di dalam elektrolit MG49-NaI (30 \% bt.) adalah didominasi oleh ion dan bukan elektron, sejurusnya membuktikan kekonduksian elektrolit polimer adalah disumbang oleh pergerakan ion yang terurai dalam sistem.

JADUAL 1. Kekonduksian ion MG49-NaI dengan berat peratus garam yang berbeza

\begin{tabular}{cc}
\hline$\%$ bt. NaI & Kekoduksian ion, $\sigma\left(\mathrm{S} \mathrm{cm}^{-1}\right)$ \\
\hline 0 & $1.00 \times 10^{-12}$ \\
10 & $2.49 \times 10^{-8}$ \\
15 & $6.05 \times 10^{-8}$ \\
20 & $8.08 \times 10^{-8}$ \\
25 & $4.23 \times 10^{-6}$ \\
30 & $8.86 \times 10^{-5}$ \\
\hline
\end{tabular}

\section{PEMERHATIAN FIZIKAL DAN MORFOLOGI}

Rajah 3 menunjukkan gambar rajah fizikal dan morfologi keratan rentas bagi sampel MG49-NaI (30 \% bt.) pada pelbagai skala pembesaran menggunakan mikroskop imbasan elektron. Sifat fizikal permukaan sampel didapati licin dan fleksibel. Meskipun kelicinan permukaan yang dipamerkan pada pemerhatian fizikal, pandangan pada keratan rentas sampel menunjukkan elektrolit polimer adalah berstruktur liang mikro. Pembentukan liang mikro boleh dijelaskan melalui proses penyingkiran selanjutnya (di dalam ketuhar vakum) residu pelarut yang terperangkap di dalam polimer perumah selepas proses penyejatan pada suhu bilik (Lee et al. 2011). Analisis morfologi pada keratan rentas bagi polimer MG49 kawalan telah dijalankan pada kajian lepas (TianKhoon et al. 2016) menunjukkan keratan rentas permukaan yang rata dengan kehadiran liang mikro. Didapati saiz dan bilangan liang mikro bertambah dengan peningkatan kepekatan garam $\mathrm{NaI}$ (Jadual 2). Fenomena ini boleh dikaitkan dengan sifat garam $\mathrm{NaI}$ yang higroskopik dan kekutuban pelarut yang tinggi. Pemerhatian ini mencadangkan berlakunya pengkompleksan iaitu interaksi antara pelarut, garam natrium iodida dan polimer perumah semasa proses penyejatan (Lee et al. 2011). Sementara
JADUAL 2. Darjah kehabluran bagi MG49-NaI dengan berat peratus garam yang berbeza

\begin{tabular}{cc}
\hline$\%$ bt. garam NaI & Peratusan kehabluran $(\%)$ \\
\hline 10 & 29.16 \\
15 & 25.47 \\
20 & 20.28 \\
25 & 17.79 \\
30 & 14.77 \\
\hline
\end{tabular}

itu, perlu dinyatakan bahawa tiada fasa pemisahan antara polimer perumah dengan kristal garam dapat diperhatikan dalam semua sampel menunjukkan campuran antara MG49 dan garam $\mathrm{NaI}$ adalah homogen.

\section{ANALISIS FTIR}

Analisis FTIR dijalankan bagi memahami perubahan struktur kimia, kumpulan berfungsi dan interaksi yang wujud dalam elektrolit polimer MG49-NaI. Kesemua spektroskopi FTIR bagi elektrolit polimer MG49-NaI yang dianalisis diberikan dalam Rajah 4. Menurut kajian terdahulu, julat frekuensi utama yang dapat diperhatikan di dalam MG49 adalah kumpulan berfungsi yang turut hadir di dalam struktur getah asli dan PMMA (TianKhoon et al. 2015). Fokus utama diberikan kepada kumpulan polar dan kumpulan berfungsi dengan atom penderma elektron, seperti atom oksigen daripada kumpulan karbonil $(\mathrm{C}=\mathrm{O})$ dan kumpulan eter $(\mathrm{C}-\mathrm{O}-\mathrm{C})$ pada rantai metil metakrilat dalam polimer MG49 (TianKhoon et al. 2016). Dapat diperhatikan di dalam Rajah 5(a), keamatan pada puncak mod regangan simetri, $v_{\mathrm{s}}(\mathrm{C}=\mathrm{O})$ dan regangan tidak simetri, $v_{\text {as }}(\mathrm{C}-\mathrm{O}-\mathrm{C})$ masing-masing pada 1726 dan $1146 \mathrm{~cm}^{-1}$ berkurang dengan penambahan garam. Walau bagaimanapun, tiada anjakan puncak yang jitu dapat dilihat pada kumpulan berfungsi karbonil $(\mathrm{C}=\mathrm{O})$ dan eter $(\mathrm{C}-\mathrm{O}-\mathrm{C})$. Hal ini mungkin anjakan puncak yang kecil pada kumpulan berfungsi tersebut tidak dapat diperoleh disebabkan resolusi imbasan yang digunakan adalah besar $\left(4 \mathrm{~cm}^{-1}\right)$. Berdasarkan kajian lepas, anjakan puncak kepada nombor gelombang yang lebih rendah adalah penting bagi menentukan kewujudan interaksi antara ion bebas dengan kumpulan berfungsi tersebut (Ahmad et al.2010). Selain itu, kehadiran puncak yang luas pada $3450 \mathrm{~cm}^{-1}$ iaitu dimiliki oleh kumpulan -OH dalam sistem elektrolit disebabkan oleh sifat semula jadi higroskopik garam NaI.
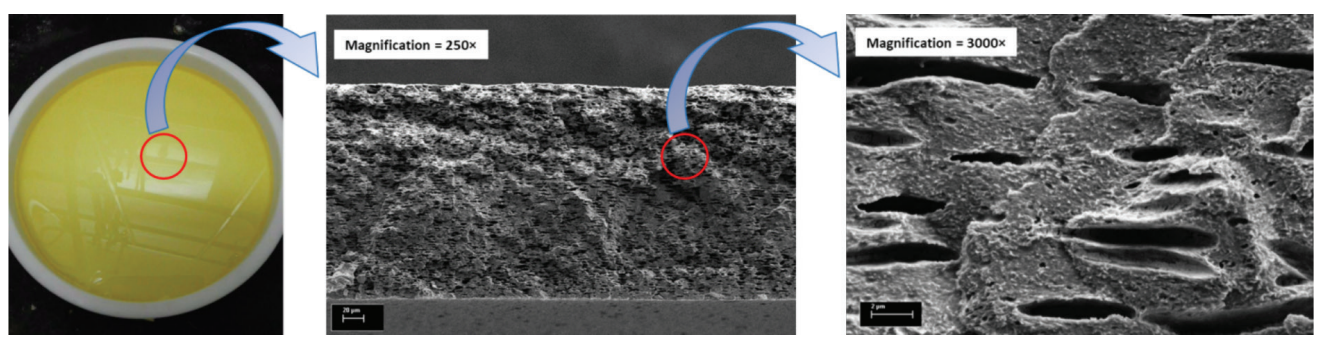

RAJAH 3. Sampel MG49-NaI (30 \% bt.) dan morfologi keratan rentas pada $250 \times$ dan $3000 \times$ pembesaran oleh SEM 
Hal ini dibuktikan oleh kehadiran puncak 'air di dalam' garam NaI pada nombor gelombang $1632 \mathrm{~cm}^{-1}$. Manakala, puncak $-\mathrm{CH}_{2}$ yang mewakili puncak poliisoprena daripada rantai getah menunjukkan tiada perubahan puncak dan keamatan yang jitu disebabkan oleh tiada interaksi yang signifikan wujud antara garam dopan dan kumpulan puncak poliisoprena daripada rantai getah.

\section{ANALISIS STRUKTUR}

Struktur dan kehabluran bagi elektrolit polimer pepejal MG49-NaI ditentukan melalui analisis pembelauan sinar-X (XRD). Rajah 5 menunjukkan difraktogram bagi elektrolit polimer pepejal MG49-NaI pada kepekatan garam yang
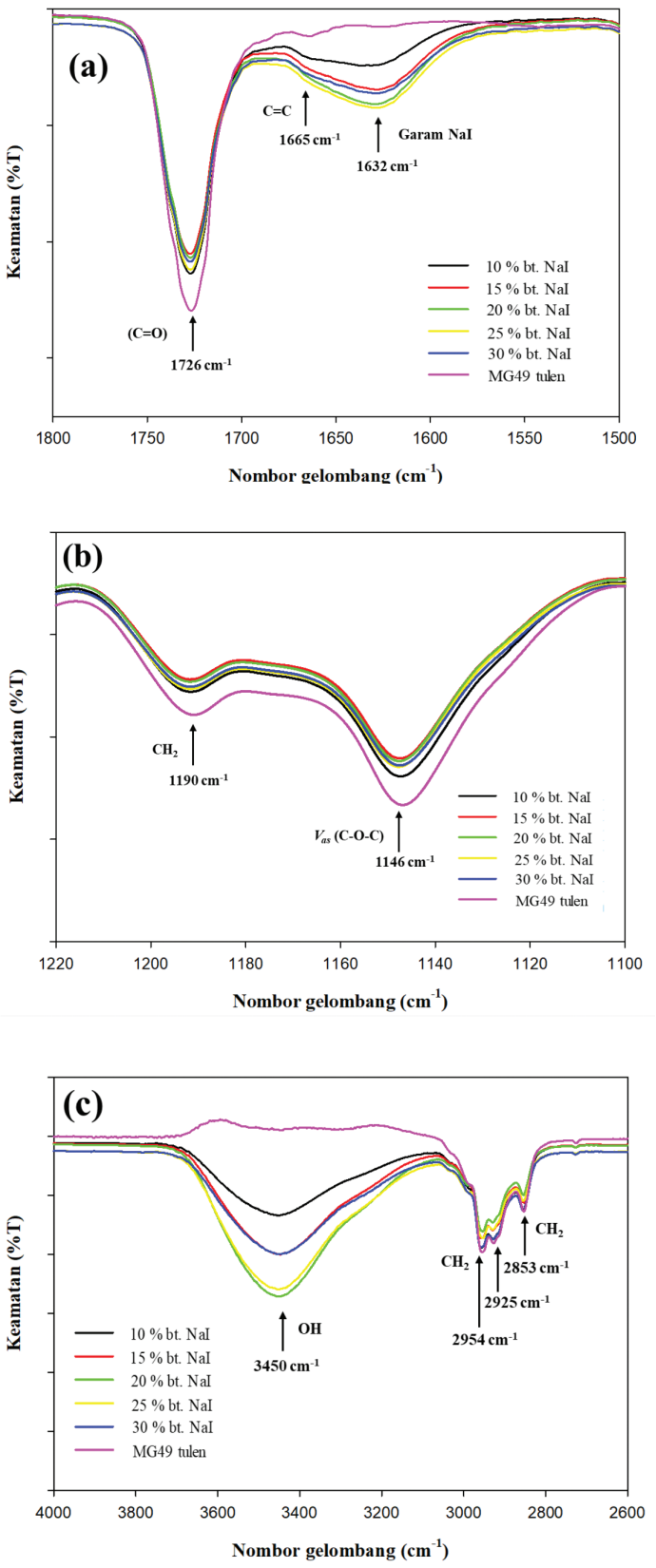

RAJAH 4. Spektroskopi FTIR bagi elektrolit MG49-NaI pada kepekatan garam $\mathrm{NaI}$ berbeza berbeza. Fasa separa hablur dapat diperhatikan dengan kehadiran bonggol yang luas pada julat sudut pembelauan 8-22 dalam MG49 kawalan. Keamatan bonggol tersebut didapati semakin berkurang dan mendatar dengan penambahan garam NaI. Jadual 2 menunjukkan darjah kehabluran bagi elektrolit MG49-NaI. Darjah kehabluran untuk polimer elektrolit telah ditentukan dengan mengira pecahan jisim antara bahagian hablur dan amorfus dalam sampel. Elektolit MG49 dengan $30 \%$ bt. garam NaI mencatatkan peratusan kehabluran yang terendah, sejajar dengan kekonduksian ion yang tertinggi iaitu $8.86 \times 10^{-5}$ $\mathrm{S} \mathrm{cm}^{-1}$. Hal ini menunjukkan sifat kehabluran sistem elektrolit polimer MG49 berkurang dengan penambahan garam NaI. Pengurangan fasa separa hablur merupakan penunjuk peningkatan fasa amorfus yang sejajar dengan peningkatan kekondusian ion. Ini disebabkan oleh pertambahan bilangan garam NaI yang terurai menjadi ion $\mathrm{Na}^{+}$dan $\mathrm{I}^{-}$, seterusnya membawa kepada pembentukan kompleks garam dengan elastomer MG49.

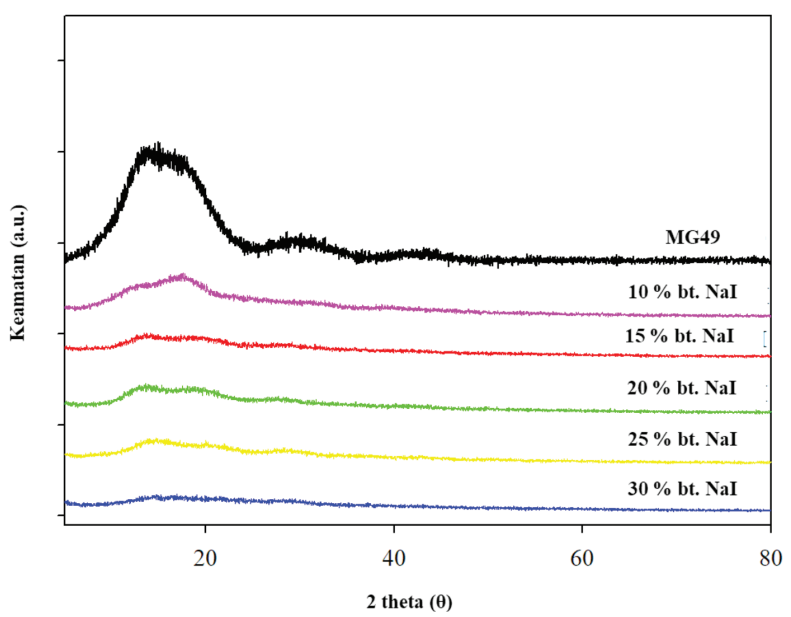

RAJAH 5. Difraktogram XRD bagi elektrolit pepejal polimer MG49-NaI

\section{PENCIRIAN FOTOVOLTAIK}

Pengukuran arus-voltan sel (FTO/TiO 2 -N719/MG49-NaI/I/ $\mathrm{Pt}$ ) dilakukan di bawah pencahayaan dalam bilik gelap pada suhu bilik bagi melihat gerak balas fotovoltaik. Elektrolit polimer dengan kekonduksian ion yang tertinggi dipilih untuk fabrikasi DSSC. Rajah 6 menunjukkan lengkung $J-V$ bagi DSSC dengan elektrolit polimer pepejal MG49-NaI

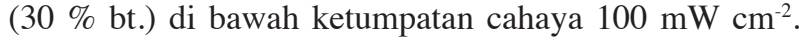
Persilangan pada paksi- $x$ dan paksi- $y$ memberikan nilai parameter fotovoltaik seperti berikut, $V_{\mathrm{oc}}=0.56 \mathrm{~V}, J_{\mathrm{sc}}=$ $1.30 \mathrm{~mA} \mathrm{~cm}^{-2}, f f=34.91$ dan kecekapan penukaran kuasa $=0.256 \%$. Silakul et al. (2017) melaporkan kecekapan DSSC yang tinggi dibantu oleh kehadiran kumpulan berfungsi seperti siloksana $(\mathrm{Si}-\mathrm{O}-\mathrm{Si})$ dan karbonil $(\mathrm{C}=\mathrm{O})$ dalam sistem elektrolit PAA-NR-co-MPS- $\mathrm{SiO}_{2}$. Oleh itu, mobiliti ion dalam sistem MG49-NaI, disebabkan oleh kehadiran kumpulan berfungsi seperti karbonil $(\mathrm{C}=\mathrm{O})$ dan eter (C-O-C). Kecekapan kuasa yang rendah dalam 
DSSC keadaan pepejal disebabkan oleh kebolehgerakan ion yang sedikit berbanding DSSC keadaan cecair (Rahman et al. 2004). Oleh yang demikian, membran dalam keadaan pepejal-kuasi atau separa pepejal disediakan dengan merendam membran elektrolit di dalam cecair elektrolit konvensional, Iodolyte dan difabrikasi di dalam peranti DSSC. Keputusan kajian memberikan nilai kecekapan yang tinggi sehingga $3.48 \%$ dengan nilai $\mathrm{V}_{\mathrm{oc}}=0.75 \mathrm{~V}$, $\mathrm{J}_{\mathrm{sc}}=12.71 \mathrm{~mA} \mathrm{~cm}^{-2}$, dan $\mathrm{FF}=37.70$; iaitu setara dengan keputusan tertinggi getah terubah suai yang digunakan oleh Silakul dan Magaraphan (2017). Tambahan pula, keputusan kajian ini adalah lebih ekonomi berbanding kajian lepas kerana penggunaan getah terubah suai yang lebih murah dan mudah disediakan berbanding getah terubah suai yang mengandungi pengisi tak organik dan penggunaan elektrolit berasaskan cecair ion yang mahal.

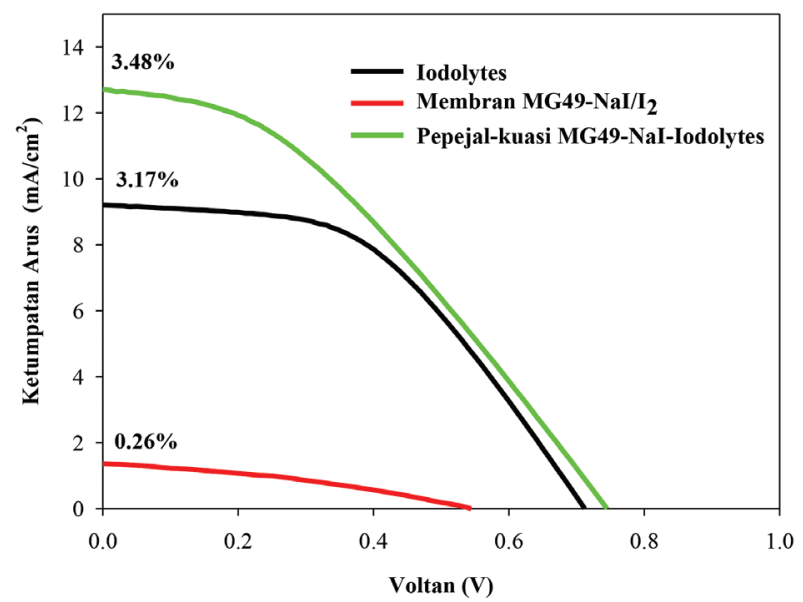

RAJAH 6. Lengkung $J-V$ DSSC keadaan pepejal dengan MG49-NaI (30 \% bt.)

\section{KESIMPULAN}

Elektrolit pepejal polimer bagi $49 \%$ poli(metil metakrilat) cangkukan getah asli (MG49) dengan natrium iodida (NaI) sebagai medium pengkonduksian ion telah berjaya disediakan dengan menggunakan teknik pengacauan larutan. Sel suria terpeka pewarna juga telah berjaya difabrikasi dengan menggunakan MG49-NaI sebagai elektrolit pepejal polimer. Nilai kekonduksian ion yang tertinggi adalah $8.86 \times 10^{-5} \mathrm{~S} \mathrm{~cm}^{-1}$ dicatatkan pada $30 \%$ bt. garam NaI. Analisis inframerah menunjukkan interaksi antara atom oksigen dengan ion natrium yang berlaku pada kumpulan berfungsi karbonil dan eter dalam polimer MG49. Analisis struktur merekodkan pengurangan fasa separa hablur dalam elektrolit polimer dengan penambahan garam NaI sehingga $30 \%$ bt. Nombor pindahan ion membuktikan kekonduksian ion elektrolit pepejal polimer MG49-NaI adalah pengkonduksi ion. DSSC keadaan pepejal-kuasi (FTO/TiO 2 -N719/MG49-NaI(30\% bt.)// $2 / \mathrm{Pt})$ yang difabrikasi telah memberikan gerak balas fotovoltaik seperti $J_{\text {sc }}, V_{\text {oc }}, f f$ dan $\eta \%$ dengan nilai masing-masing
$12.71 \mathrm{~mA} \mathrm{~cm}^{-2}, 0.75 \mathrm{~V}, 37.70$ dan $3.48 \%$. Kajian awal ini telah membuktikan bahawa MG49 sebagai induk elektrolit polimer dalam DSSC mempunyai potensi yang tinggi dalam aplikasi DSSC. Malahan, ia adalah murah, senang diproses dan mempunyai strukutr kimia yang mudah. Hal ini juga akan membuka ruang perkembangan dan meningkatkan harga pasaran getah yang merupakan salah satu komoditi yang penting bagi Malaysia. Walau bagaimanapun, kajian selanjutnya perlu dijalankan supaya kecekapan fotovoltaik ini dapat terus dipertingkatkan.

\section{PENGHARGAAN}

Penulis ingin memberikan penghargaan kepada Pusat Pengajian Sains Kimia dan Teknologi Makanan, Institut Penyelidikan Tenaga Suria (SERI), Pusat Pengurusan Penyelidikan dan Instrumentasi (CRIM) dan Universiti Kebangsaan Malaysia (UKM) kerana membenarkan kajian ini dijalankan dengan jayanya. Penyelidikan ini dijalankan dengan menggunakan geran UKM-TD-2015-008 dan MI2018-002 dengankerjasama pelajar tahun akhir program teknologi kimia, Cik. Nur Syazwani bt Hasmi (A145961) serta profesor pelawat, Prof. Dr. Daniel Brandell dari Universiti Uppsala, Sweden.

\section{RUJUKAN}

Ahmad, A., Lien, P.C. \& Su'ait, M.S. 2010. Elektrolit pepejal polimer $49 \%$ poli (metil metakrilat) cangkukan getah asli - litium tetrafluoroborat. Sains Malaysiana 39(1): 65-71.

Ahmad, A., Rahman, M.Y.A., Harun, H., Su'ait, M.S. \& Yarmo, M.A. 2012. Preparation and characterization of $49 \%$ poly (methyl methacrylate) grafted natural rubber (MG49)stannum (IV) oxide $\left(\mathrm{SnO}_{2}\right)$-lithium salt based composite polymer electrolyte. International Journal of Electrochemical Science 7: 1-17.

Ali, A.M.M., Subban, R.H.Y., Bahron, H., Yahya, M.Z.A. \& Kamisan, A.S. 2013. Investigation on modified natural rubber gel polymer electrolytes for lithium polymer battery. Journal of Power Sources 244: 636-640.

Ataollahi, N., Ahmad, A., Hamzah, H., Rahman, M.Y.A. \& Mohamed, N.S. 2012. Preparation and characterization of PVdF-HFP/MG49 based polymer blend electrolyte. International Journal Electrochemical Science 7: 6693-6703.

Bella, F. 2015. Polymer electrolytes and perovskites: Lights and shadows in photovoltaic devices. Electrochima Acta 175: 151-161.

Bruce, P.G., Evans, J. \& Vincent, C.A. 1988. Conductivity and transference number measurements on polymer electrolytes. Solid State Ionics 28-30: 918-922.

Buraidah, M.H., Shah, S., Teo, L.P., Chowdhury, F.I., Careem, M.A., Albinsson, I. \& Mellander, B.E. 2017. High efficient dye sensitized solar cells using phthaloylchitosan based gel polymer electrolytes. Electrochimica Acta 245: 846-853.

Burschka, J., Pellet, N., Moon, S.J., Humphry-Baker, R., Gao, P., Nazeeruddin, M.K. \& Grätzel, M. 2013. Sequential deposition as a route to high-performance perovskitesensitized solar cells. Nature 499(7458): 316-319.

Glasse, M.D., Idris, R., Latham, R.J., Linford, R.G. \& Schlindwein, W.S. 2002. Polymer electrolytes based on modified natural rubber. Solid State Ionics 147(3-4): 289-294. 
Grätzel, M. 2003. Dye-sensitized solar cells. Journal of Photochemistry and Photobiology C: Photochemistry Reviews 4(2): 145-153.

Green, M.A. 2001. Third generation photovoltaics: Ultra-high conversion efficiency at low cost. Progress in Photovoltaics: Research and Applications 9(2): 123-135.

Green, M.A., Emery, K., Hishikawa, Y., Warta, W., Dunlop, E.D., Levi, D.H., Ho-Baillie, A.W.Y. 2017. Solar cell efficiency tables (Version 45). Progress in Photovoltaics: Research and Applications 25(4): 333-334.

Ibrahim, S., Ahmad, A. \& Mohamed, N.S. 2018. Comprehensive studies on polymer electrolyte and dye-sensitized solar cell developed using castor oil-based polyurethane. Journal of Solid State Electrochemistry 22(2): 461-470.

Ibrahim, S.,Ahmad,A.\& Mohamed, N.S. 2015. Characterization of novel castor oil-based polyurethane polymer electrolytes. Polymers 7(4): 747-759.

Kakiage, K., Aoyama, Y., Yano, T., Oya, K., Fujisawa, J.I. \& Hanaya, M. 2015. Highly-efficient DSSCs with collaborative sensitization by silyl-anchor and carboxy-anchor dyes. Chemical Communication 51(88): 15894-15897.

Kumutha, K.,Alias, Y. \& Said, R. 2005. FTIR and thermal studies of modified natural rubber based polymer electrolytes. Ionics 11(5-6): 472-476.

Lee, T.K., Ahmad, A., Farina, Y., Dahlan, H.M. \& Rahman, M.Y.A. 2011. Preparation and characterization of solid polymeric electrolyte of poly(vinyl) chloride-low molecular weight LENR50 (70/30)- $\mathrm{LiClO}_{4}$. Polymers and Polymer Composites 21(7): 449-456.

Malaysia Energy Information Hub (MEIH). http://meih.st.gov. my/statistics. Diakses pada 28 Januari 2018

Mathew, S., Yella, A., Gao, P., Humphry-Baker, R., Curchod, B.F., Ashari-Astani, N., Tavernelli, I., Rothlisberger, U., Nazeeruddin, M.K. \& Grätzel, M. 2014. Dye-sensitized solar cells with $13 \%$ efficiency achieved through the molecular engineering of porphyrin sensitizers. Nature Chemistry 6 : 242-247.

Mohan, K., Dolui, S., Chandra, B., Bora, A., Sharma, S. \& Kumar, S. 2017. A highly stable and efficient quasi solid state dye sensitized solar cell based on polymethyl methacrylate (PMMA)/carbon black (CB) polymer gel electrolyte with improved open circuit voltage. Electrochimica Acta 247: 216-228.

Nazeeruddin, M.K., Angelis, F.D., Fantacci, S., Selloni, A., Viscardi, G., Liska, P., Ito, S., Takeru, B. \& Grätzel, M. 2005. Combined experimental and DFT-TDDFT computational study of photoelectrochemical cell ruthenium sensitizers. Journal of the American Chemical Society 127(48): 1683516847.

Nazir, K., Aziz, A.F., Yahya, M.Z.A. \& Ali, A.M.M. 2017. Ionic conductivity studies of epoxidized poly(methyl methacrylate)grafted natural rubber based gel polymer electrolyte for dye sensitized polymer solar cell. AIP Conference Proceedings 1877: 040003-1 - 040003-8.

Ng,H.M., Ramesh, S. \& Ramesh, K. 2015.Efficiency improvement by incorporating 1-methyl-3-propylimidazolium iodide ionic liquid in gel polymer electrolytes for dye-sensitized solar cells. Electrochimica Acta 175: 169-175.

O'regan, B. \& Grätzel, M. 1991. A low-cost, high-efficiency solar cell based on dye-sensitized colloidal $\mathrm{TiO}_{2}$ films. Nature 353(6346): 737-740.

Rahman, M.Y.A., Salleh, M.M., Talib, I.A. \& Yahaya, M. 2004. Effect of ionic conductivity of a PVC- $\mathrm{LiClO}_{4}$ based solid polymeric electrolyte on the performance of solar cells of ITO/TiO $/ \mathrm{PVC}_{2} \mathrm{LiClO}_{4} /$ graphite. Journal of Power Sources 133(2): 293-297.

Silakul, P. \& Magaraphan R. 2013. Gel polymer electrolyte from poly(acrylamide) coated on natural rubber latex by topologycontrolled emulsion polymerization for dye sensitized solar cells application. Advanced Materials Research 747: 325-328.

Silakul, P. \& Magaraphan, R. 2014. Gel polymer electrolyte from ozonolysis of poly(3-(trimethoxysilyl) propyl methacrylate) graft on natural rubber latex for natural dye sensitized solar cells application. Advanced Materials Research 844: 357360 .

Silakul,P. \& Magaraphan, R. 2017. Polymer electrolyte developed from natural rubber -polyacrylic acid co trimethoxysilyl propyl methacrylate grafted fumed silica and its application to dye sensitized solar cell. Polymer Composites doi: 10.1002/ pc.24648 (in press).

Suruhanjaya Tenaga. 2016. Malaysia Energy Statistics Handbook 2016. Putrajaya: Suruhanjaya Tenaga

Su'ait, M.S., Rahman, M.Y.A. \& Ahmad, A. 2015. Review on polymer electrolyte in dye-sensitized solar cells (DSSCs). Solar Energy 115: 452-470.

Su'ait, M.S., Noor, S.A.M., Ahmad, A., Hamzah, H. \& Rahman, M.Y.A. 2012. Preparation and characterization of blended solid polymer electrolyte $49 \%$ poly(methyl methacrylate)grafted natural rubber: Poly(methyl methacrylate)-lithium tetrafluoroborate. Journal of Solid State Electrochemistry 16(6): 2275-2282.

Su'ait, M.S., Ahmad, A., Hamzah, H. \& Rahman, M.Y.A. 2009 Preparation and characterization of PMMA-MG49- $\mathrm{LiClO}_{4}$ solid polymeric electrolyte. Journal of Physics D: Applied Physics 42(5): 55410.

TianKhoon, L., Ataollahi, N., Hassan, N.H. \& Ahmad, A. 2016. Studies of porous solid polymeric electrolytes based on poly(vinylidene fluoride) and poly(methyl methacrylate) grafted natural rubber for applications in electrochemical devices. Journal of Solid State Electrochemistry 20(1): 203-213.

TianKhoon, L., Hassan, N.H., Rahman, M.Y.A., Vedarajan, R., Matsumi, N. \& Ahmad, A. 2015. One-pot synthesis nanohybrid $\mathrm{ZrO}_{2}-\mathrm{TiO}_{2}$ fillers in $49 \%$ poly(methyl methacrylate) grafted natural rubber (MG49) based nano-composite polymer electrolyte for lithium ion battery application. Solid State Ionics 276: 72-79.

Waterman, J.A., Heij, G.E.L. \& Hoorn, H.V. 1967. Grafting of methyl methacrylate on isoprene rubber. Journal of Chemical Technology and Biotechnology 17: 121-125.

Wu, J., Lan, Z., Lin, J., Huang, M., Huang, Y., Fan, L. \& Luo, G. 2015. Electrolytes in dye-sensitized solar cells. Chemical Reviews 115(5): 2136-2173.

Shuhib Mamat, Mohamad Faizzi, Mohd Sukor Su'ait*, Norasikin Ahmad Ludin \& Kamaruzzaman Sopian

Solar Energy Research Institute (SERI)

Universiti Kebangsaan Malaysia

43600 UKM Bangi, Selangor Darul Ehsan Malaysia

Nurul Akmaliah Dzulkurnain

UM Power Energy Dedicated Advanced Center (UMPEDAC) Wisma R\&D 
Universiti Malaya, Jalan Pantai Baharu 59990 Kuala Lumpur, Wilayah Persekutuan Malaysia

Azizan Ahmad

School of Chemical Sciences and Food Technology Faculty of Science and Technology

Universiti Kebangsaan Malaysia

43600 UKM Bangi, Selangor Darul Ehsan

Malaysia

Loh Kee Shyuan \& Lee Tian Khoon

Fuel Cell Institute (FCI)

Universiti Kebangsaan Malaysia

43600 UKM Bangi, Selangor Darul Ehsan

Malaysia
Daniel Brandell

Department of Chemistry

Ångström Laboratory, Structural Chemistry

Uppsala University

Sweden

*Pengarang untuk surat-menyurat; email: mohdsukor@ukm. edu.my

Diserahkan: 7 Mac 2018

Diterima: 13 Julai 2018 